\title{
Tsunami Risk Mapping of Lumajang District Using Geographic Information System (GIS)
}

\author{
Amien Widodo ${ }^{1 *}$, Dwa Desa Warnana ${ }^{2}$, Juan Pandu Gya Nur Rochman ${ }^{3}$, Firman Syaifuddin ${ }^{4}$, Erik Sapta \\ Perbawa $^{5}$, Ary Iswahyudi ${ }^{6}$, Wien Lestari ${ }^{7}$ \\ Geophysical Engineering Department, Civil Engineering, Environment and Terrestrial Faculty, Institut Teknologi \\ Sepuluh Nopember, Surabaya, Indonesia ${ }^{1,2,3,4,7}$
}

Informatics Engineering Department, Engineering Faculty, Madura Islamic University ${ }^{5,6}$

*Corresponding Address: explorer.wien@gmail.com

\begin{abstract}
Indonesia lied among the three of world major plates so that several districts along the southern coast of Java Island were vulnerabled to the tsunami including Lumajang. South coast of Lumajang had high population density and settlements and high levels of government and economic activity. Therefore, it is necessary to know the level of insecurity and vulnerability to the tsunami in order to be utilized as input of mitigation data for the preparation of regional spatial plans (RTRW) based on tsunami risk level. The objective of this research is to arrange the regional risk map for tsunami in Lumajang Regency using Geographic Information System (GIS) through approach of insecurity and vulnerability analysis of tsunami. The insecurity rate is analyzed based on seismicity map and run-up data of tsunami event in Lumajang District. Vulnerability approach used multicriteria such as land elevation, slope, coastal morphometry, land use, distance from the coast and distance from the river. The methodology that was used included data collections of both primary and secondary data such as satellite imagery of earth map, Lumajang statistical data. Each vulnerability data variable was processed to result a weighting and scores that its become the parameters for making a regional tsunami vulnerability map. The results showed three level of risks in five subdistricts that directly adjacent to the Southern Coast such as Yosowilangun, Kunir, Tempeh, Pasirian, and Tempursari. The high tsunami risk which covered almost along the coast, the ramps morphology, without any protective vegetation and human activities at the site while the medium of tsunami risk which were in areas with elevation more higher than the coastal and the low of tsunami risk had variations of topography, quite far from the coast and less human activities.
\end{abstract}

Keywords—insecurity, vulnerability, south coast,

\section{INTRODUCTION}

L umajang is one of the districts in East Java that enter the red zone of disaster means that all types of disasters that occur in Indonesia such as landslides, floods, droughts, earthquakes and tsunamis can occur in Lumajang District. Lumajang was closed to the subduction zone of two plates, Eurasia and Australia, which are only about $250 \mathrm{~km}$ from the coast. This was the reason for Lumajang district that it included into the category of disaster risk earthquake and the heaviest tsunami in East Java Province with two other areas, Pacitan and Tulungagung Regency based on the release of the Department of Energy and Natural Resources of East Java province related to the earthquake potential in East Java. Nearly $90 \%$ of tsunami disaster in Indonesia is caused by tectonic earthquake (rochman, 2011). Lumajang Beach had a stretch of $76 \mathrm{~km}$ from Tempur Sari to Yosowilangun. The character of the beach in Lumajang was to have large waves of layers that can reach up to 3 meters high. This is the hallmark of the south coast scene.

Tsunami comes from Japanese. "Tsu" means port, "nami" means wave so that it is generally interpreted as the great tide of the sea at the Port. From this sense, Tsunamis can be interpreted as ocean waves with long periods caused by impulsive disorders of the seafloor.
Impulsive disorder could be tectonic earthquake, volcanic eruption or landslide (warnana, 2010). The most common cause of tsunamis in Indonesia is submarine earthquakes which due to the position of Indonesia located at the confluence of three submarine plate boundaries (subduction zones).

Tsunami has a speed that is directly proportional to the greater ocean depth into the ocean. At the beach, the speed of the run-up Tsunami can be reduced to about 25 - $100 \mathrm{~km} / \mathrm{h}$. This wave can destroy life in coastal areas. Even lowlands can become stagnant to form a new ocean. Tsunamis can knock down buildings, bridges, damage roads, cut off power lines, telephone networks and other infrastructure. Clean water facilities, agricultural land and soil fertility were disrupted due to contaminated seawater. The tsunami is a threat that can cause huge losses and casualties. Therefore, tsunami disaster mitigation is the crucial process of pursuing various preventive measures to minimize the negative impact of the expected tsunami disaster (widodo, 2013)

Vulnerability by ISDR (2004) is a condition of society or community determined by physical, social, economic and environmental factors that increase the inability to cope with a disaster. Mitigation is a series of efforts to reduce disaster risks, both through physical development and awareness and increased capacity to deal with disaster threats (Law No.24 Year 2007). One of the mitigation measures is mapped tsunami vulnerability and 
determine tsunami risk level in Lumajang District, East Java using Geographic Information System.

The risk of a disaster have three variables: hazards, vulnerability and capability aspects (Diposaptono dan Budiman, 2006). The relationship of these three variables is formulated to the equation below:

$$
\text { Risk }(R)=\frac{\text { Hazard }(H) \times V \text { Ulnerability }(V)}{\text { Capacity }(C)}
$$

\section{METHOD}

Determination of tsunami risk level is done in two stages, namely the determination of insecurity and tsunami vulnerability. Based on the research flow in figure 1, Determining the level of tsunami insecurity was conducted with the aim to determine the areas that had the disaster potential by making a map of seismicity and tsunami prone maps. Seismicity map is a map that it described the tectonic setting plate and the distribution of earthquake points in a region. The data was got from BMKG and USGS last century. Mapping of points of earthquake and tectonic plate setting was useful to know and analyze the distribution of earthquake and tsunami center that ever happened in Lumajang District.

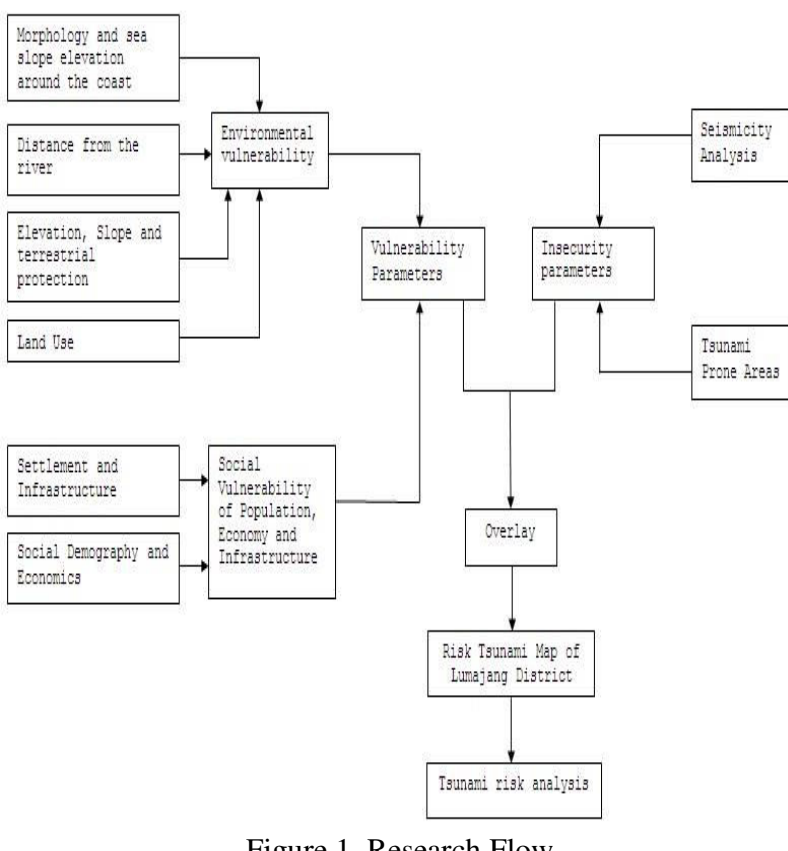

Figure 1. Research Flow

Mapping of tsunami prone areas is done by mapping the high run-up data (tsunami height point data) based on the Lumajang District tsunami field survey data. The data was dispensed with Cell Based Modeling (CBM) method and described the level of tsunami vulnerability. The reference used to describe the tsunami risk level is the BNPB disaster guideline (2012) which showed the relationship of damage rate to tsunami run-up height (Table 1).

Table 1.

Relationship Level Damage And High Run-Up Tsunami (BNPB, 2012)

\begin{tabular}{|c|c|c|c|}
\hline No & $\begin{array}{c}\text { Run-Up } \\
\text { Height/Wave (m) }\end{array}$ & Threat Level & $\begin{array}{c}\text { Damage } \\
\text { Rate }\end{array}$ \\
\hline 1 & $>3$ & Tinggi & Besar \\
\hline
\end{tabular}

\begin{tabular}{|c|c|c|c|}
\hline 2 & $1-3$ & Sedang & Sedang \\
\hline 3 & $<1$ & Rendah & Kecil \\
\hline
\end{tabular}

The vulnerability analysis examined in this study were the vulnerability of the environment, infrastructure and social vulnerability of population. The environmental susceptibility parameters could be dispatched and described in the tsunami risk matrix. The parameters of social and infrastructure vulnerability were overlaid with tsunami risk maps to obtain a tsunami risk and infrastructure risk map.

Tsunami risk was determined by overlaying vulnerability and insecurity data. All parameters would be dispensed with the CBM method. The value of each class is based on the following formula (Pasek, 2007)

$N=\sum B_{i} x S_{i}$

where

$\mathrm{N}$ : Total of weight value

$\mathrm{B}_{\mathrm{i}}$ : Weight of each criteria

$\mathrm{S}_{\mathrm{i}}$ : Score of each criteria

i: Parameter

\section{RESULT AND DISCUSSION}

The main activities undertaken were consist of:

1. Literature study and secondary data collection on territoriality (administration, geology, and land use) and societies (social demography and economy).

2. Field data collection, which includes:

a. Mapping Bathymetry

b. Mapping of settlement / residence

3. Determining the level of vulnerability to the Tsunami a. Againts the elevation

b. Againts the slope

c, Againts Coastal Morphology

d. Againts Landuse

e. To the distance from the shoreline

f. To the distance from the river

Determining the level of tsunami insequrity required several input data such as the history of earthquakes and tsunamis that occurred in the South Coast, bathymetry measurement data that is the topographic measurement of the seabed and modeling the run-up of tsunami waves.

Based on USGS (United States Geological Survey) data, the seismicity occured in the study area and its surroundings from 1900 to present were more than 1000 earthquakes, but the earthquake that could caused a tsunami on condition if the earthquake is over $6,5 \mathrm{SR}$, and the epicenter was at a depth of less than $60 \mathrm{~km}$ from the seabed there are only 4 earthquakes that had the potential to become a source of Tsunami, as presented in Table 2 and Figure 2

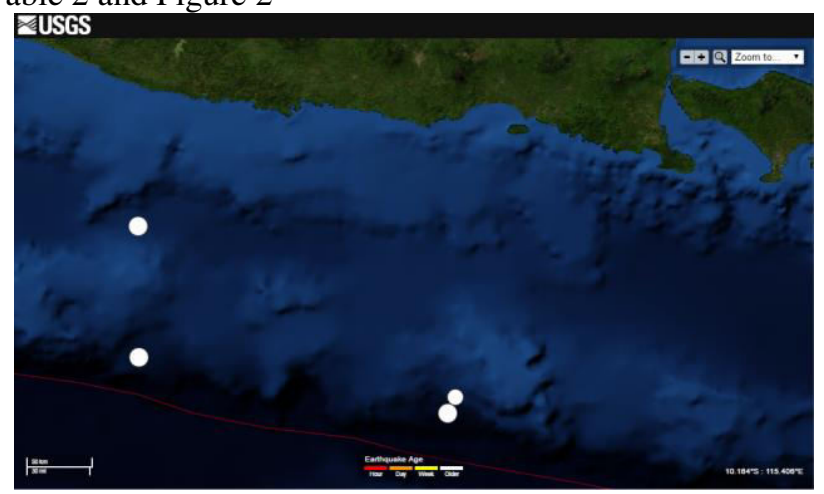


Figure 2. Tsunami Potential Earthquake Point

Table 2.

Earthquake data that could potentially cause Tsunami

\begin{tabular}{|c|c|c|c|c|}
\hline $\begin{array}{c}\text { Years } \\
\text { Of } \\
\text { Events }\end{array}$ & $\begin{array}{c}\text { Latitude } \\
\left({ }^{0} \mathrm{~S}\right)\end{array}$ & $\begin{array}{c}\text { Longitude } \\
\left({ }^{0} \mathrm{E}\right)\end{array}$ & $\begin{array}{c}\text { Magnitude } \\
(\mathrm{M})\end{array}$ & $\begin{array}{c}\text { Depth( } \\
\mathrm{km})\end{array}$ \\
\hline $\begin{array}{c}03-06- \\
1994\end{array}$ & 10.362 & 112.892 & 6.6 & 25.9 \\
\hline $\begin{array}{c}02-06- \\
1994\end{array}$ & 10.477 & 112.835 & 7.8 & 18.4 \\
\hline $\begin{array}{c}10-09- \\
1926\end{array}$ & 9.156 & 110.617 & 7.1 & 35 \\
\hline $11-09-$ & 10.080 & 110.623 & 7.6 & 15 \\
1921 & & & & \\
\hline
\end{tabular}

The bathymetry mapping was conducted in the southern waters of Lumajang District as shown in Figure 3. Mapping work was generally divided into two, the first work was a depth measurement of the waters using Garmin GPS MAP 585 with a depth reach reaches 1500 $\mathrm{ft}$ (dual frequency) and $900 \mathrm{ft}$ (single frequency). Second work was tidal observation of sea water using measuring beam with length 5 meter.

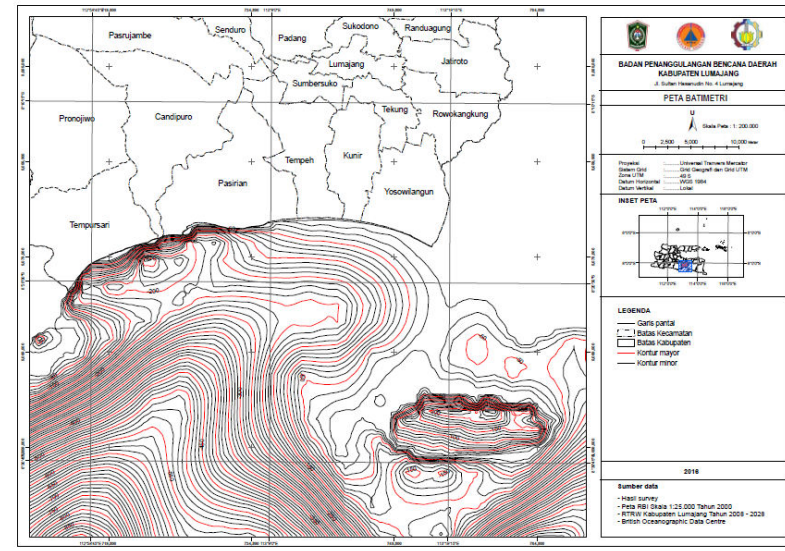

Figure 3. South Sea Bathimetry Map of Lumajang District

Determination of vulnerability zones required the preparation of maps of environmental vulnerability and social vulnerability of population, economy and infrastructures. Sources of data were apart from the survey results also came from RBI Map scale 1: 25000 and map of Spatial Planning and Lumajang District 2008-2028.

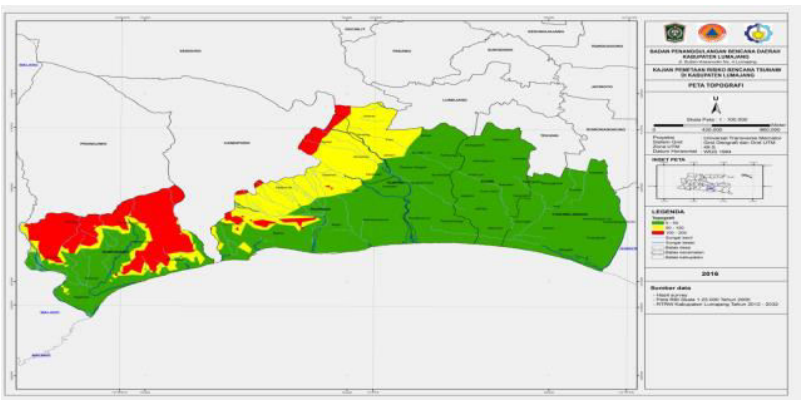

Figure 4. Landscape Map

Figure 4 showed the sub-districts that border directly with the South Coast had low topography (green colour).

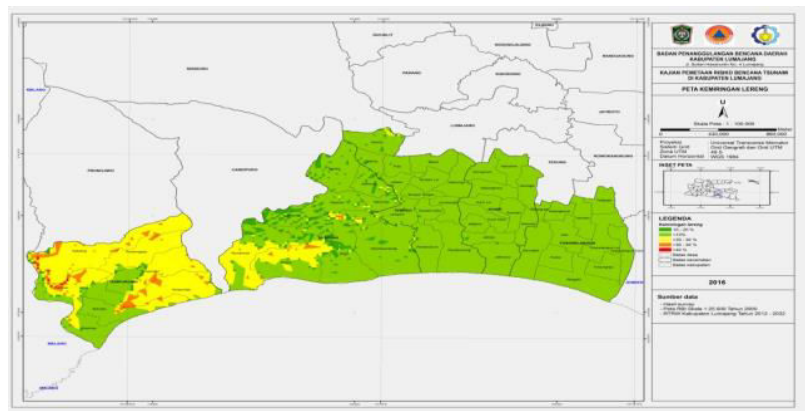

Figure 5. Slope Map

Figure 5 showed a fairly high slope slope located in the sub-districts of Tempursari and Pasirian (brown-yellow), while the other sub-districts were dominant lowlands (green).

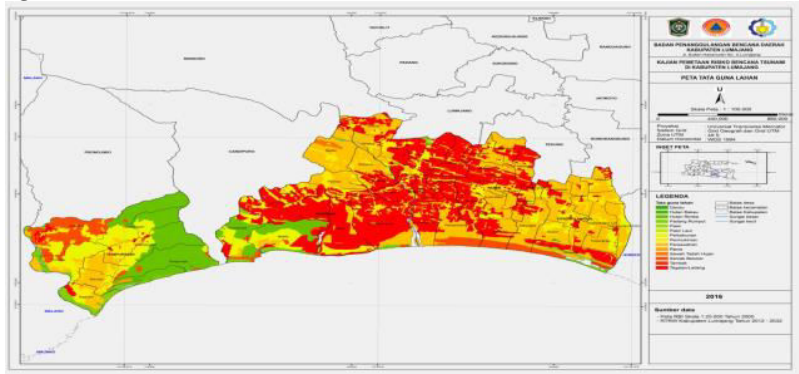

Figure 6. Landuse Map

The land-use map (figure 6) showed in Tempursari sub-district had lakes and forests (yellow), while Pasirian, Tempeh and Kunir sub-districts have rain-fed fields, ponds, shrubs and fields (red). The dominant plantations and rice fields are located in East Lumajang namely Yosowilangun District (orange).

The environmental vulnerability overlay map can be classified into 3 classes that such as low, medium, and high risk areas (figure 7). High environmental susceptibility almost located along the coast of Lumajang study areas, especially in the eastern and western coastal areas and in some of Pasirian Subdistrict, mainly in river estuaries. High vulnerability were on the border of Yosowilangun, Pasirian and Tempursari districts. Low vulnerability exists in all sub-districts along the coast (red).

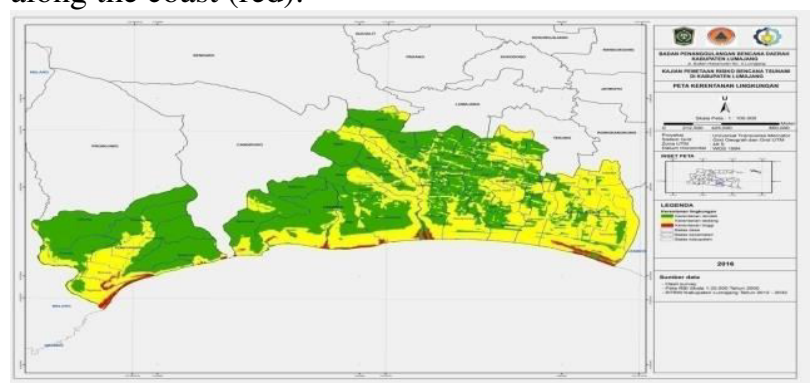

Figure 7. Environment Vulnerability Map

The results of this field survey in addition to used for crosscheck data was also used to update residential data that would be utilized in the stages of data processing (figure 8). 


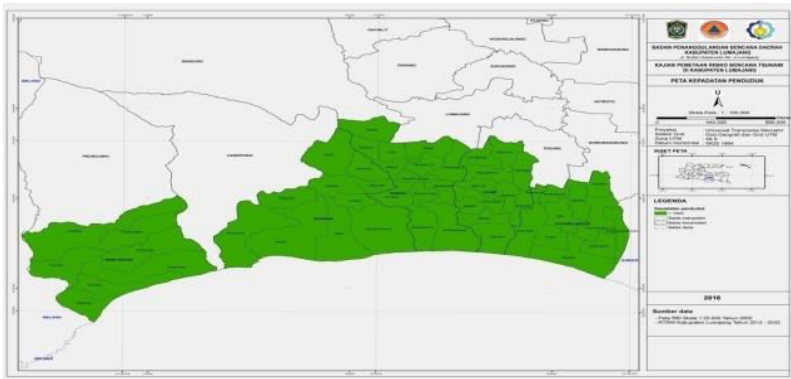

Figure 8. Vulnerability Map of Population Density

Infrastructure vulnerability maps were obtained by covering the distance of the bridge, the South Cross Lane (JLS), and the Landline network with the distance from the shoreline resulting in 3 classes (figure 9). Risk maps were high if the distance $0-200 \mathrm{~m}$ that it was located in sub-district of Tempursari and Yusowilangun. Infrastructure vulnerability were in Tempursari and Yusowilangun sub-districts, while low infrastructure vulnerability lied in Pasirian Subdistrict, Tempeh Subdistrict and Kunir Sub-district.

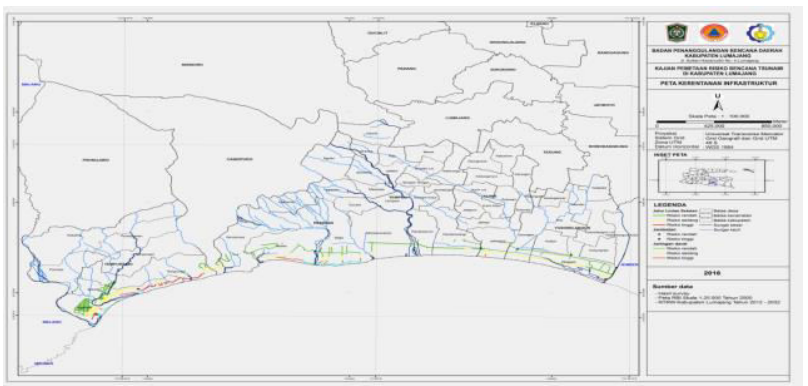

Figure 9.Infrastucture Vulnerability Map

Based on the results of the environmental vulnerability map that it overlaid with Tsunami Run-Up Map, a Tsunami Risk Map was obtained in the study area. The Tsunami Run-Up Map was available by modeling a tsunami based on tsunami data in the Indian Ocean in 1994 with a tsunami wave height of 8 meters

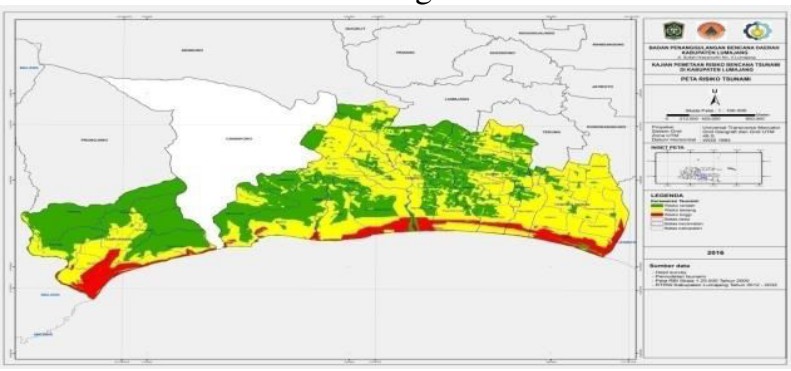

Figure 10. Tsunami Risk Map In Study Area (5 Sub-Districts)

Generally, 5 (five) sub districts in the study area were tsunami prone areas with varying levels of risk ranging from high to low (Figure 10). Areas with high tsunami risk (marked with the red colour) in coastal areas had sloping morphology, with no protective vegetation and human activity at the site. While medium tsunami risk (yellow colour) was closed to the coastal with topographic variations of about $10-20 \%$ and its lands was used for paddy fields, low-risk areas (green colour) had high elevation, steep morphology, there were a lot of vegetation and minimal human activity in it.

\section{CONCLUSION}

The conclusion of the South Lumajang Tsunami disaster risk mapping study is
1. In general, the potential risk areas for tsunamis were occured through the coastal areas of Lumajang District. The coastal area were covered by 5 sub-districts which directly adjacent to South Beach. There were Yosowilangun subdistrict, Kunir sub-district, Tempeh sub-district, Pasirian sub-district and Tempursari subdistrict.

2. Tsunami vulnerability in 5 sub-districts in coastal Lumajang could be categorized in 3 risk levels :

A. High Tsunami Risk

Areas with high tsunami vulnerability (red) were flat to sloping (topography 0-50 meters above sea level) with low elevation (less than 10\%) and covering the coastal areas of the study area. This zone had land that were used as a settlement, rice field and mangrove forest. Subdistricts and villages classified as highly prone to tsunamis are Tempursari Sub-district located in some coastal areas including Tegalrejo, Bulurejo, Tempurrejo, Tempursari and Pundungsari villages. Pasirian subdistrict was included in the very high risk zone is located on the coast of Bago Village and Selokawarawar Village. The high tsunami vulnerability in Tempeh Sub-district were in Pandanarum Village at the South, Pandanwangi Village and it was equal to the border river of Central Tempeh village with Lempeni. Villages in Kecamatan Kunir with high tsunami risk were located in the central to southern part of Jatimulyo Village and the southern coastal area of Wotgalih Village in Yosowilangun subdistrict.

\section{B. Tsunami Risk Medium}

Areas with moderate risk (yellow) had a high topography of 50-200 m above sea level with variation of slope $10-20 \%$. This zone had land that were used as rice fields, plantations, fields or moor. Villages in Tempursari sub-district which included in tsunami risk zone were Tegalrejo Village North, Bulurejo North, Tempurrejo West and East, Tempursari West, Central and West Pundungsari, West Purorejo Village along the river and Kaliuling Village The west along the river equivalent. Levels of risk vulnerability were presented in almost all villages in Pasirian Subdistrict, Tempeh Subdistrict, Kunir and Yosowilangun Sub-district. Level of vulnerability is in the District Candipuro were located at the South and East, part Timut Jarit, the North Kloposawit, Penanggal and Sumbermujur. The southern part of Tumpeng village and the middle part of Desa Sumberwuluh.

\section{Low Tsunami Risk}

Low risk areas (light green) had topographic variations of about 50-200 meters above sea level with variations of $10-40 \%$. This zone were consists of bushes, ponds and fields or fields. Villages in Tempursari sub-district belonging to low tsunami zone were in Purorejo Village Middle to the East, East Tempurejo Village, East Tempursari Village, East and West Pundungsari Village and most of Kaliuling Village. Villages in Pasirian subdistrict included in low risk were located in the central Bago Village, Central Selokawarawar Village, Northern Part of Bades Village, West part of Condro Village, most of Kalibendo village, northern Madurejo and Pasirian villages. Low risk in Kecamatan Tempeh were generally located at a fairly high elevation that is located in the northern part of Jetisari Village, West part of Tempeh 
Lor Village, West Part to North Village of Besuk, East to North Pulo, East of Gesang Village and West of Jokarto Village . Low vulnerability in Kunir District were found in Jatirejo and Jatimulyo villages whereas the low risk in Yosowilangun District was in the southern part of Wotgalih Village.

\section{ACNOWLEDGEMENT}

Praise the presence of Allah SWT so that the final report "Tsunami Risk Mapping Assessment in Lumajang District" can be completed. This report is structured as a follow up of research activities undertaken by a team of researchers from the Institute for Research and Community Service (LPPM) - Sepuluh Nopember Institute of Technology (ITS) Surabaya. The content of this final report is an overview of the activities that have been undertaken in relation to the tsunami risk mapping review in Lumajang District.

Hopefully this final report is useful and can provide an information related with Lumajang government plan.

\section{REFERENCES}

[1] K. Lida, "Magnitude, Energy and Generation Mechanism of Tsunami and A Catalogue of Earthquake associated with Tsunami," International Union Geodesy and Geophysics Monograph, pp. 24 : 7-17, 1963.

[2] I. Pasek, Penentuan Zona Potensial Mutiara Dengan Cell Based Modelling, Bogor: Program Studi Ilmu dan Teknologi Kelautan, 2007.

[3] Haryadi, "Kemungkinan Penerapan Konsep Sistem Seting Dalam Penemukenalan Penataan Ruang Kawasan," Berkala Arkeologi, Yogyakarya, 1995.

[4] S. Rohadi, "Distribusi Spasial dan Temporal Seismotektonik Wilayah Subduksi Jawa," Megasains 1 (4), pp. 180-188.

[5] R. W. A. W. U. Y. Daniel Siahaan, "Web-Based Tsunami Early Warning System," IPTEK The Journal for Technology and Science, vol. 24, no. 3, p. 23, 2013.

[6] D. D. W. W. U. R. A. Ria Asih Aryani Soemitro, "Assesment to the Local Site Effects during Earthquake Induced Landslide Using Microtremor Measurement (Case Study: Kemuning Lor, Jember Regency-Indonesia)," Journal of Basic and Applied Scientific Research, vol. 1, no. 5, pp. 412-417, 2011.

[7] Z. Abidin, Penentuan Posisi Dengan Receiver GPS Satu Frekuensi, Status Dan Permasalahannya, Bandung: Departemen Teknik Geodesi, 2005.

[8] Ingham, Hydrography For The Surveyor And Engineering, Stuttgart, Germany: Geodetic Institute University, 1984.

[9] ISDR, Living With Risk : A Global Review of Disaster Reduction Initiatives, Geneva: UNISDR, 2004.

[10] Yuwono, Buku Ajar Hidrografi-1, Surabaya: Program Studi Teknik Geodesi, 2005.

[11] W. A. B. J.G.N.R. Pandu, "Microtremor's application for the mapping Potential Soil Liquefaction In The Coastal Area of Pacitan," in Seminar Nasional Teori dan Aplikasi Teknologi Kelautan, Surabaya, 2011. 